\title{
Articles
}

\section{What helps in the Scenery in Systemically-Oriented Work with People}

\section{Stanislava Ševčíková}

Motto: A great many people think they are thinking when they are merely rearranging their prejudices.

William James

\begin{abstract}
Postmodern time appeals many questions dealing with the manner of the cooperation among the people in different context, $\mathrm{f}$. e. in helping professions such as social pedagogy, social work or school system professionals. In the article, the author deals with the question of what is systemic approach, what constructs it uses for the understanding of "problem" and what is achieved by the systemic approach in dealing with the principles of beauty and usefulness by the respecting of the other in his otherness as an offer to the traditional view of using "specialism" as a tool assigned to a helping professional in a helping relation.
\end{abstract}

Key words: systemic approach, helping profession, respect, beauty, usefulness, recognising of other in the otherness.

\section{Abstrakt}

Postmoderní doba klade mnoho otázek spojených se způsobem spolupráce mezi lidmi v nejrůznějších profesionálních kontextech, např. v pomáhajících profesích jako je sociální pedagogika, sociální práce nebo profesionálové ve školství. V textu se autor- 
ka zabývá otázkou, co je systemický přístup, jaké konstrukty užívá pro definici pojmu "problem" a jakých výsledků dosahuje užitím principů jako krása, užitek při respektu druhého v jeho odlišnosti jako nabídka k tradičnímu pojetí odbornosti vyhrazeném pomáhajícímu profesionálovi v pomáhajícím vztahu.

Klíčová slova: systemický přístup, pomáhající profese, respect, krása, užitek, uznání druhého v jeho odlišnosti.

\section{Introduction}

Not many views of the helping process are available to helping professions. There could be used the altruistic ideas and those are to be used as a basis for the help to clients (cf. Musil, 2006), which is a very common approach, or the helping professionals are concentrated on cultivating their work with clients and a usefully formulated object of co-operation (cf. Ludewig, 2011). The thus-formulated objective can also be seen as an effective prevention of the burnout syndrome (Brock, Grady, 2002). The research question the author deals with the question of what is systemic approach, what constructs it uses for the understanding of "problem" and what is achieved by the systemic approach in dealing with the principles of beauty and usefulness by the respecting of the other in his otherness as an offer to the traditional view of using "specialism" as a tool assigned to a helping professional in a helping relation. There will be discussed the questions of whether and how helping professionals are able to distinguish between "reality" in the context of perceiving the client's problem and his family and life context; how to distinguish between what is objectively observable and measurable (first-order reality) and how a fact is evaluated and what meaning is attributed to that fact (second-order reality) (cf. Watzlawick 1998, Watzslawick, Bavelas, Jackson, 1999). All these individual building blocks of constructivist thought can help social workers better work with clients in asking usefully formulated questions (cf. Schweitzer, Schlippe, 2001), handling life better, becoming stronger and facing difficult life situations bravely.

\section{Systemic approach}

The systemic approach is based on the premise that the human world consists of systems and these human systems produce speech and meanings (Schlippe, Schweitzer, 2001). ${ }^{1}$ The system needs to be understood, through communication within the system.

\footnotetext{
1 Any therapeutic systems or systems providing help are problem-determined systems and as such they do not belong in everyday life events. The therapist becomes a part of the system and, hence, part of the problem; he is not someone "outside" but rather "within". He is a "conversation artist", one who is able to create room
} 
Thus, the systemic approach derives its understanding of an individual from observation of the family which is characterised as a sociocultural system with all its elements (stability, hierarchy, power and control). The systemic approach sees reality as a social construct. Emphasis is placed especially on interrelation, interaction (cf. also Gergen, 2012). Post-structuralism, from which the systemic approach stems, asserts that people's interaction is the activity which creates meaning (Ludewig, 2011). Consequently, the meaning of communication and mutual interactions is created by interactions rather than naming, which is only secondary. The fact that the social world is understood as one constructed by language makes it impossible to find and formulate generally valid laws. Thus, social structuralists believe that the designation of a phenomenon leads to its substance and is therapeutic - naming leads to recovery (Schweitzer, Schlippe, 2001).

In the systemic approach, a problem defines a problem-determined system which comes to the helping worker. Consequently, not every system is a problem-determined system (Schlippe, Schweitzer, 2001, Ludewig, 2011).

Thus, the systemic approach is one which has developed from the family therapy that showed the need to work not only with the client himself but to include the whole family system in the helping intervention. It is no longer the individual but the whole system which becomes the client in the systemic approach. For example, Schlippe and Schweitzer (2001) refer to a case of the Milan Institute of Family Therapy where a schizophrenic client's mother and his son (brother of the client) had to be included in the therapy because it would be impossible to ascertain without working with the whole family why the client suddenly worsened. It was only the presence of the admired brother and his communication with the mother that suggested a possible way of resolving the problems.

Family therapists have noticed that the system is homeostatic, maintains balance and that, in a problem-determined system, it is the problem which keeps the system together. The systemic approach closely observes how the client constructs the problem and his ideas about himself, others and the world. These trends are currently also called postmodern trends for their proximity to a paradigm which respects the autonomy of multiple original realities within social reality. This means in practice that while maintaining ethical principles, the helping professional respects clients' wishes in decisions pertaining to their lives and believes that they make decisions which are the best possible at the time (cf. Ludewig, 2011, Schlippe, Schweitzer, 2001, Dallos, Vetere, 2009).

The narrative theory developed by Michael White is yet another trend in the development of the building of the systemic approach (cf. White, Epston, 1990, Payne, 2005). Narrative therapy draws inspiration from postmodern thought and social constructivism (cf. Berger, Luckmann, 1966). Narrative therapy is based on the assumption that

for, and facilitate, conversation in order to resolve a problem. Clients are encouraged to assume responsibility for their life; they are experts in their own problems and the therapist helps them look at these problems from various angles. 
the reality lived by people ceases to correspond to the ideas and stories they or their close ones have created about themselves and they therefore create a new story, either independently or with the help of a helping worker (as an analogy: they knit or sew a new piece of clothing), which better corresponds to their life settings and enables them to cope with life difficulties better and more virogously. As an example, instead of building his self-understanding as someone deserving compassion because he lacks biological parents, a child in a children's home or foster family learns to see himself as a smart child who willingly helps others, has a feel for their needs or is perhaps good at playing football.

According to Ludewig (2011), systemic work is centred on the notions of respect (respect for oneself, clients, society, shared work), beauty (beauty of co-operation, looking for and enabling new and unique decisions of clients, c. f. also Karfíková, 1998) and usefulness (usefulness of co-operation; the worker follows the principle "be useful, do not help" $)^{2}$. Respect for the client has become an important moment of successful co-operation ${ }^{3}$; systemic therapists "respect" the client in his perception of the world and goals and attempt to think about clients by approaching their language and conversing (languaging) in that language (cf. Miller, 2004) or, as Gergen (2012) puts it, the client together with the worker form and interpret their story. The aforementioned principle of respect also means that helping workers do not fulfil their own needs but rather attempt to be helpful through an explicitly expressed form of co-operation with the client, i.e. the client should primarily perceive the usefulness of the worker's help with the sole exception of assuming control in systemic understanding (Schweitzer, Schlippe, 2001, Ludewig, 2011). According to Gergen (2009, 2012), who is considered to be the founder of social constructionism - the concept that we construct or form the social world in human relationships and interpersonal communication; a human being is no longer perceived as the "Self", hermetically enclosed in the body and defining itself in relation to other entities (see Leibniz' monadology, cf. Mates, 1986), but is rather a relationship with others, involved in social contexts, communicating and responding to projects and identities of others (Gergen, 2012).

Systemic doctrines adhere to the theory of social constructivism. We can describe the latter in a simplified way in line with Paul Watzlawick (1998) in the example of the distinction between two kinds of reality: first-order reality, i. e. that of the objective world and objective facts, most often such that can somehow be quantified and measured (the dimensions of a room, outside or inside temperature, etc.), and this quantification can be replicated. Second-order reality, especially social reality, incorporates the meanings that individual facts have for us. These individual facts are described by

2 Similarly, the Global Standards for Social Work Education and Training refer to the necessity of "recognition of the dignity, worth and the uniqueness of all human beings" in social work education and training (cf. Global, 2007 and Ševčíková, 2007).

3 In the same way as one of the American fathers of humanistic psychology Carl Rogers abandoned his expert approach in the middle of the 20th century and established the "person-centred therapy" (cf. Rogers, 1995). 
language and, in the most radical meaning of the word, anything that has not been named and voiced is non-existent (Watzslawick, 1998). According to Kenneth Gergen (2009), a human neither a nor a reality but a social construct; the notions of "truth", "objectiveness", "reason" and "knowledge" become relational - a human always has a relationship to something. These notions are also endowed with a historic context and are conditional. Gergen (2004) asserts that this does not mean the necessity to cease using them (including the notions of "creativity", "intuition", "instincts"," "personality traits") but to be radically aware of their historic context and loss of any entitlement to objectiveness or full testimony. Steve de Shazer says the same by saying that "boundaries do not exist, boundaries happen".

\section{Basic concepts of systemic approach}

\section{Problem as a result of a system}

In the constructivist approach, a problem is not defined through "causes" (see the different, objectivist view of the world). In this approach to man and the world, causes are not "removed" because this is often impossible. Looking at complex systems from the perspective of causes and consequences can even lead to their destruction.

According to Ludewig (2011), negative experience with the need for change represents a problem. If a person endeavours for a change in vain, meeting a major refusal and similar reactions instead of a positive response from people around him, he will unwillingly stick to his old behaviour or fall into psychotic behaviour that brings him at least the care of hospital staff.

Úlehla (1999) also mentions the "problem-holder principle"; put simply, if the client has manners acceptable for society but problematic for himself, the client is the problem-holder and control sets in; if his unacceptable manners are a problem for the worker, the latter is the problem-holder and control is again employed ${ }^{4}$. Musil (2006) adds that there is also a situation where the manners are unacceptable for both the client and for the worker and both of them are problem-holders.

\section{Assumptions as the base of perception of reality}

Assumptions are the basis for every person's construction of the world. Assumptions can be understood as certain basic beliefs about truths and values concerning oneself, others and how the world works.

4 Nevertheless, the aspect of totalitarian systems arises - manners acceptable for the majority or those in power suddenly become extremely relative. 
I consider that reflecting on one's own assumptions (about himself, others, the world, values, etc.) (cf. Gergen, 2004, 2009, de Shazer, 2011, Ludewig, 2011) is a prerequisite for working with others. One of the basic principles of systemic self-experience consists in a radical reflection of everything that the helping worker has learned so far about himself, others and the world. According to Ludewig (2011), the substance of systemic therapy lies in the reduction of complexity of phenomena while preserving complexity as such (cf. also Olsson, Sjöstedt, 2004).

Reflecting on one's assumptions and ideas about the world can help find a view of a social reality which is different than usual and such "being different" helps clients. The homeostasis of the system (cf. Dallos, Draper, 2010) ${ }^{5}$ avoiding changes from the outside was much stronger. As soon as the external pressures relaxed the family was able to do what it thought was correct and develop new rituals of community.

Together with their past, people carry the consequences of their individual and social development. These are reflected in their understanding of how life and the world work, what is useful to do, what actions lead to success, how to satisfy their needs, what desires and needs are forbidden. Assumptions show how a person perceives and interprets himself, others and the surrounding world in general. It is obvious that the perceptions and assumptions of every person are unique and individual (cf. Schlippe, Schweitzer, 2001). Every family system has its own ways of talking or keeping silent about enjoyable things and problems, its own ways of coping with difficult situations (for example, passivity and remaining static when encountered with a problem, escaping from the problem, withdrawal), its own rituals and, last but not least, its own taboos.

A child from a children's home who must struggle to find his own path will have different assumptions about himself from those of a single child of elderly parents and those of a child from a large village family. Similarly, the gender structure of assumptions about success and possibilities in life will differ in men and women (cf. Brown, Augusta-Scott, 2007).

The objective of helping workers is to look for and uncover these assumptions in order to find in them new possibilities, to broaden their range, encourage willingness to change, look for and support new original solutions of a specific system, including through non-intervention (see below, on offering help and assuming control), confidence that the system has all competences to develop new ways of action.

5 I understand the homeostasis of a system as a behaviour in which it maintains its balance even at the expense of a problem being created. The feedback which shows the system its inacceptability enourages it to behave in a way which endeavours to maintain the system whole. However, this concept expects someone, usually the helping worker, to define what is "correct", what is expected and what is the present condition (of distress). 


\section{Art of reframing}

It does not help much to the helping intervention if we label the client with negative characteristics (cf. Mattila, 2001). Characteristics such as lazy, egoistic, close-mouthed, dependent do not mean much in terms of usefulness of helping co-operation and, most importantly, for coping with and addressing a difficult situation (cf. Bartlett, 1970). Labelled with a characteristic like these, the counterpart in communication will either have to keep the the position which he considers justified or lose face and, for the sake of appearances, admit that what he considers correct and relevant is in fact wrong. On the other hand, looking for positive connotations in the behaviour of a communication partner can enable communication which was seemingly no longer possible. For example, a dependent person can be seen as someone who endeavours for co-operation with others to join them on a common path or as a prudent individual who wants to avoid errors.

\section{Recognising the other in his/her otherness by the example of poor or ethnical origin}

Systemic respect, beauty and usefulness are related to the concept of "recognising the other", which involves respect, recognition and non-judging differences - qualities that inspire the philosophical views of S. de Beauvoir in her 1949 book "The Second Sex" (Beauvoir, 1989). A life and thought partner of J. P. Sartre, Beauvoir contemplates the fate of the "other" and the "different" - meaning women in society, calling for recognition of and respect for this otherness, preserving the full dignity of an individual (f. e. poor one, different sex or ethnical origin).

The dominant view of present Euro-American society, which sets values claiming to be valid and recognised by the majority is that every human has the chance to change his or her life through his/her own efforts and work. Middle- and, sometimes, upper class in Latin America who worked in 1960s with and endeavoured to improve literacy of the poor, such as the Brazilian P. Freire (2000a, 2000b), shared the same view. These middle class members were able to transform their negative attitude to the poor and began working with people in slums and rural areas. By doing this, they achieved solidarity and new literacy for most of Latin America. It proved essential to strive for recognition of the human dignity of not only the rich, but also the poor in their distinction and otherness. The "voiceless" poor had their voice in (mostly) educated "delegates" who were able to look at the poor through their own eyes and, simultaneously, use the means available to the rich and powerful (education, media, universities, psychology).

The endeavour for recognition of and respect for the other and his/her dignity in his/her otherness is one of the starting points of the liberation movement in philosophy, psychology, history and theology in Latin America (cf. Gutiérrez, 1992, Dussel, 1989). 
I am placing under this concept all activities that the people involved considered to belong to "desire for liberation", mostly at universities where new educational concepts emerged, old interpretations of history and man were abandoned and new ways were sought to help"the people" prosper in society or learn to read and write. Among others, the following areas are worth mentioning: pedagogy of liberation, theology of liberation, but also liberation psychology), emerging in the 1960s as a response of intellectuals (people who had the opportunity to obtain education in Europe or America and, after returning home, saw the destitution of their homeland, especially the unscrupulous exploitation of the poor and the illiterate by the rich. Liberation (pedagogy, philosophy, psychology and theology of liberation) was to be achieved not "from above" but directly from within the "poor Other" (cf. the concept of recognition and respect for the other in his/her otherness); they were to become a history written from the angle of the poor and not the rich as had always been the case. For a Czech reader these thoughts appear to resonate with those of real communism which many of them experienced, but a deeper examination reveals that they contain a deep wisdom - provided that the poor also respect and recognise the other (for example, the rich) in his/her otherness.

In this context, the "other" is the poor who no longer wants to be enslaved and no longer wants to be poor. The "other" is undergoing transformation, rebirth - still in the mode of "being the other, the different" (Ševčíková, 2001), but shows a will to transition from this condition to a better one - together with the different "other", the one whom the majority calls the "rich".

A large part of the culture of the liberation movement in humanities at universities, including in Europe, endeavoured to form new hermeneutics, a new culture of "recognition of and respect for the other and in his/her existence" (Metz in Gutiérrez, 1992: 14).

\section{Conclusion}

In the presented article, I attempted to reflect the basic elements of the systemic approach, concentrating primarily on the understanding of problem, art of reframing and concepts and notions of beauty, respect and usefulness in professional and reflected social work, social pedagogy and other helping professions. Clients of helping professionals are often socially excluded men and women limited in their resources. The task of helping professionals is to look for respect and recognition of their value outside the mainstream. Primary task of helping professionals is to be intrinsically aware, and specifically in relation to clients, that there are also other values that shape the dignity, beauty and value of a human being. And as part of the dignity and beauty of helping professional' help, they are able to use both verbal and non-verbal communication to pass this message to their clients and help them find the dignity, beauty and respect for their lives and life values in the respect to the other in his otherness. 


\section{References}

Bartlett, H. (1970). The common base of social work practice. Washington: National Association of Social Workers.

Beauvoir, de, S. (1989). The Second Sex. New York: Vintage Books.

Berger, P. L. \& Luckmann, T. (1966). The Social Construction of Reality: A Treatise in the Sociology of Knowledge, Garden City, NY: Anchor Books.

Brock, B. L. \& Grady, M. L. (2002) Avoiding Burnout: A Principal's Guide to Keeping the Fire Alive, Thousand Oaks: Corwin Press.

Brown, C., Augusta-Scott, T. (2007). Narrative therapy. Making meaning, making lives. Thousand Oaks, London, New Delhi: Sage.

Dallos, R, Draper, R. (2010). An Introduction To Family Therapy: Systemic Theory and Practice. Maidenhead: Open University Press.

Dallos, R., Vetere, A. (2009). Systemic Therapy and Attachment Narratives. London, New York: Routledge.

Dussel, E. (1989). Prophetie und Kritik. Entwurf einer Geschichte der Theologie in Lateinamerika, Fribourg: Brig.

Freire, P. (2000a). Pedagogy of Hope. London, Oxford, New York, New Delhi, Sydney: Bloomsbury Academic.

Freire, P. (2000b). Pedagogy of Freedom: Ethics, Democracy, and Civic Courage, Lanham: Rowman \& Littlefield Publishers.

Gergen, M. M., \& Gergen, K. J. (2012). Playing with Purpose: Adventures in Performative Social Science. Walnut Creek: Left Coast Press.

Gergen, K. J. (2004). Die 'Oldstream' - Psychologie wird verschwinden wie die Dinosaurier! Forum Qualitative Social Research / Sozialforschung, 5(3). [on line] [19/2/2016] retrieved from: www. qualitative-research.net/index.php/fqs/article/view/553/1196\#zi

Gergen, K. (2009). An Invitation to Social Construction. London, Thousand Oaks, New Delhi: Sage.

Global Qualifying Standards for Social Work Education. Supplement časopisu International Social Work, 2007.

Gutiérrez, G. (1992). Theologie der Befreiung, Mainz: Matthias-Grünewald-Verlag.

International Federation of Social Workers., \& International Association of Schools of Social Work. (2007). International definition of the social work profession; Ethics in social work, statement of principles; Global standards for the education and training of the social work profession. Place of publication not identified: International Federation of Social Workers (IFSW)/International Association of Schools of Social Work (IASSW).

Karfíková, L. (1998). De esse ad pulchrum esse. Schönheit in der Theologie Hugos von St. Viktor. Brepols: Turnhout.

Ludewig, K. (2011). Základy systemické terapie. Praha: Grada.

Mates, B. B. (1986). The Philosophy of Leibniz: Metaphysics and Language: Metaphysics and Language. Oxford, New York, Toronto: Oxford University Press.

Mattilla, A. (2001). Seeing Things in a New Light. Reframing in Therapeutic Conversation. Helsinki: Rehabilitation Foundation.

Metz, J. B. (1992). Vorvort. In Gutiérrez, G. Theologie der Befreiung. Mainz: Matthias-GrünewaldVerlag.

Miller, G. (2004). Becoming Miracle Workers: Language and Meaning in Brief Therapy. New Brunswick: Transaction Publishers.

Musil, L. (2006). Coping with dilemmas: Working conditions and interactions of social workers with their clients. Stassfurt: BK-Verl.

Payne, M. (2006). Narrative therapy: An introduction for counsellors. London: SAGE Publications. 
Rogers, C. (1995). On Becoming a Person: A Therapist's View of Psychotherapy. New York: Houghton Mifflin Company.

Shazer, de, S. (2011). Zázračná otázka: krátká terapie zaměřená na řešení. Praha: Portál.

Schlippe, von, A. \& Schweitzer, J. (2001). Systemická terapie a poradenství. Brno: Cesta.

Ševčíková, S. (2007). Mezinárodní a český kontext Globálních kvalifikačních standardů vzdělávání v sociální práci vydaných IFSW a IASSW. Sociální práce/Sociálna práca 6(4): 49-54.

Ševčíková, S. (2001). Theologie der Befreiung als Ruf nach Anerkennung des Gott des Lebens. Zur Gottessuche von Gustavo Gutiérrez. Diplomarbeit, Passsau.

Úlehla, I. (1999). Umění pomáhat. Praha: Slon.

White, M. \& Epston, D. (1990). Narrative means to therapeutic ends. New York, London: Norton.

Watzlawick, P. \& Vybíral, Z. (1998). Jak skutečná je skutečnost?: Mylné představy, klamání, porozumění. Hradec Králové: Konfrontace.

Watzlawick, P., Bavelas, J. B. \& Jackson, D. D. (1999). Pragmatika lidské komunikace. Hradec Králové: Konfrontace.

\section{Contact:}

Dipl.-Theol. Univ. Stanislava Ševčíková, Ph.D.

Soukromá psychoterapeutická praxe, www.psychoterapie-brno.com

E-mail: stana.sevcikova@gmail.com

Author's profile:

Stanislava Ševčíková (Dipl.-Theol. Univ., Ph.D.) works as an external lecturer at the Department of Educational Sciences at the Faculty of Arts of Masaryk University in Brno, as an educator for children with educational troubles and also as a psychotherapist. As a researcher and teacher she deals with theories and methods of social work, especially systemic and narrative approaches, existential approach, logotherapy and crisis intervention, as well as supervision and topics related to helping work with people. She is also active as psychotherapist. 